\title{
Analysis of optimal habitat for captive release of the sea cucumber Holothuria scabra
}

\author{
Daniela M. Ceccarellii ${ }^{1}$, Murray Logan ${ }^{2}$, Steven W. Purcell ${ }^{1,3, *}$ \\ ${ }^{1}$ National Marine Science Centre, Southern Cross University, PO Box 4321, Coffs Harbour, NSW 2450, Australia \\ ${ }^{2}$ Australian Institute of Marine Science, PMB No. 3, Townsville MC, QLD 4810, Australia \\ ${ }^{3}$ WorldFish, PO Box 500, Penang 10670, Malaysia
}

\begin{abstract}
The success of marine stocking programs hinges on releasing hatchery-produced juvenile animals into the optimal marine habitat. This study sought to identify optimal microhabitat features of coastal seagrass meadows for juvenile sea cucumbers Holothuria scabra, a species cultured widely for stock restoration, sea ranching and sea farming. Groups of 25 juveniles were released into 30 replicate $1 \mathrm{~m}^{2}$ open sea pens embedded into sediments in a coastal bay of New Caledonia at sites with varying biotic and physical features. Survival after 8 to $10 \mathrm{~d}$ ranged from 0 to $100 \%$ and averaged $77 \%$. Boosted regression tree analyses found that different variables affected survival, growth and burying behaviour. Survival was significantly higher at shallow depths with intermediate seagrass cover $(\sim 42 \%)$. Growth rate was significantly higher at comparable intermediate seagrass cover $(\sim 34 \%)$ and for smaller juveniles, presumably displaying compensatory growth. Burying frequency of juveniles was largely explained by habitat variables, notably a high organic carbon content of sediments and shallow seawater depths. Juveniles survived better where they buried more frequently, providing empirical evidence of a predatoravoidance mechanism. Our findings reveal that marine animals can display non-linear responses to habitat features such as seagrass cover. These marine invertebrates should be released in habitats that optimize survival, growth and behaviours and be spread among multiple sites to mitigate against stochastic mortality events. This experimental approach offers clear advantages over factorial designs for identifying optimal habitats for captive-release programs.
\end{abstract}

KEY WORDS: Stock enhancement · Sea cucumber · Habitat requirements · Regression modelling Survival $\cdot$ Predation $\cdot$ Invertebrate $\cdot$ Seagrass

\section{INTRODUCTION}

Rising global demand for marine resources and overfishing of wild stocks have led to widespread interest in stocking aquaculture-reared animals into the wild for restocking, sea ranching and sea farming (Bell et al. 2005, 2008). There is a long history of stocking finfish into the sea, but invertebrate stocking is a relatively recent endeavour (Bell et al. 2005, Bartley \& Bell 2008, Leber 2012). Well-documented programs include the restocking and sea ranching of scallops, sea urchins, abalone and other bivalves (Arnold 2008, Okuzawa et al. 2008), blue crabs (Davis et

\footnotetext{
${ }^{*}$ Corresponding author: steven.purcell@scu.edu.au
}

al. 2005, Hines et al. 2008, Zohar et al. 2008), mud crabs (Okuzawa et al. 2008), lobsters and crayfish (Bannister \& Addison 1998), queen conch (Brownscombe et al. 2015), giant clams (Andréfouet et al. 2005, Gomez \& Mingoa-Licuanan 2006, Okuzawa et al. 2008), topshell gastropods (Castell et al. 1996, Purcell 2004a, Purcell \& Cheng 2010) and sea cucumbers (Lovatelli et al. 2004, Battaglene \& Bell 2008, Purcell 2012, Juinio-Meñez et al. 2017). Initial efforts were plagued by high mortality of released juveniles and low economic returns due to a lack of knowledge about the technology and ecology of releasing juveniles into the wild, leading to studies to improve

() The authors 2018. Open Access under Creative Commons by Attribution Licence. Use, distribution and reproduction are unrestricted. Authors and original publication must be credited. 
release strategies and track the survival of released animals (Bartley \& Bell 2008). Experimental designs and scientific approaches to determine the habitats to release juvenile invertebrates have been basic (Table 1) and need improvement to optimise the success of stocking programs.

Mortality in the wild of hatchery-produced juveniles of a variety of invertebrate taxa is typically high soon after release, often occuring during the first day or within the first month (Crowe et al. 2002, Oliver et al. 2005, Dixon et al. 2006, Purcell \& Simutoga 2008). Key determinants of survival of the juveniles include the size at release and the density and habitat in which animals are released (Munro \& Bell 1997, Bell et al. 2005). Size at release can influence mortality rates because predation risk declines as juveniles grow larger, but releasing larger juveniles is more costly (Molony et al. 2003, Leber et al. 2005, Roberts et al. 2007, Purcell \& Simutoga 2008). Animals released in suboptimal habitats either migrate out of the areas in search of more suitable conditions, are eaten rapidly because they are vulnerable to predators (Bartley \& Bell 2008) or perish through environmental stress or malnutrition (Dance et al. 2003), competitive exclusion and other stressful conditions (Childress \& Herrnkind 2001, Purcell 2004b, Purcell \& Cheng 2010). Density of released individuals can also be important, as mortality can be density-dependent for many invertebrate species (Beal \& Kraus 2002, Hines et al. 2008).

Table 1. Examples of captive release studies on marine invertebrates that specifically tested the effects of habitat

\begin{tabular}{|c|c|c|c|c|}
\hline Species & Common name & Location & Design & Reference \\
\hline \multirow[t]{3}{*}{ Holothuria scabra } & \multirow[t]{3}{*}{ Sandfish } & Solomon Islands & $\begin{array}{l}\text { Factorial design (habitat types, } \\
\text { mangrove-seagrass combinations } \\
\text { and coral reef types) }\end{array}$ & Dance et al. (2003) \\
\hline & & New Caledonia & $\begin{array}{l}\text { Exploratory; effects of microhabitat } \\
\text { (seagrass composition, sediment size, } \\
\text { organic content) examined in multi- } \\
\text { variable biplot }\end{array}$ & Purcell \& Simutoga (2008) \\
\hline & & Papua New Guinea & $\begin{array}{l}\text { Exploratory; effects of microhabitat } \\
\text { (seagrass composition, sediment size, } \\
\text { organic content) examined in multi- } \\
\text { variable biplot }\end{array}$ & Hair et al. (2016) \\
\hline Penaeus esculentus & Brown tiger prawn & Northern Australia & $\begin{array}{l}\text { Factorial design, substratum types } \\
\text { ( } 2 \text { seagrass habitats and } 1 \text { bare } \\
\text { substratum), effects on predation }\end{array}$ & Kenyon et al. (1995) \\
\hline Penaeus semisulcatus & Green tiger prawn & Northern Australia & $\begin{array}{l}\text { Factorial design, comparing growth } \\
\text { rates between } 2 \text { levels of plant } \\
\text { biomass }\end{array}$ & Loneragan et al. (2001) \\
\hline Callinectes sapidus & $\begin{array}{l}\text { Chesapeake Bay } \\
\text { blue crab }\end{array}$ & Chesapeake Bay & $\begin{array}{l}\text { Factorial design, } 3 \text { depths, } 4 \text { coves, } \\
2 \text { positions in the river }\end{array}$ & Hines et al. (2008) \\
\hline Carcinus maenas & Shore crab & Western Sweden & $\begin{array}{l}\text { Factorial design, habitat types } \\
\text { (mussels, algae, eelgrass, open sand) }\end{array}$ & Moksnes (2002) \\
\hline Jasus edwardsii & Red rock lobster & New Zealand & $\begin{array}{l}\text { Factorial design, } 3 \text { shelter shapes, } \\
4 \text { hole sizes, pairwise tests }\end{array}$ & Booth \& Ayers (2005) \\
\hline Panulirus argus & $\begin{array}{l}\text { Caribbean spiny } \\
\text { lobster }\end{array}$ & Florida & $\begin{array}{l}\text { Factorial design, hard bottom vs. } \\
\text { seagrass habitats }\end{array}$ & Behringer et al. (2009) \\
\hline Palinurus elephas & $\begin{array}{l}\text { European spiny } \\
\text { lobster }\end{array}$ & Sicily & $\begin{array}{l}\text { Factorial design, } 3 \text { shelter shapes, } \\
5 \text { shelter sizes, } 2 \text { substrate slopes }\end{array}$ & Gristina et al. (2009) \\
\hline Mercenaria mercenaria & Hard clam & North Carolina & $\begin{array}{l}\text { Factorial design, } 3 \text { levels of } \\
\text { seagrass \% cover }\end{array}$ & Irlandi (1994) \\
\hline \multirow[t]{2}{*}{ Lobatus gigas } & \multirow[t]{2}{*}{ Queen conch } & Bahamas & $\begin{array}{l}\text { Factorial design, } 3 \text { levels of } \\
\text { seagrass \% cover }\end{array}$ & Ray \& Stoner (1995) \\
\hline & & Bahamas & $\begin{array}{l}\text { Factorial design, habitat types } \\
\text { (seagrass, rubble) and regression }\end{array}$ & Brownscombe et al. (2015) \\
\hline Haliotis laevigata & Greenlip abalone & South Australia & $\begin{array}{l}\text { Factorial design, } 2 \text { habitat types } \\
\text { (layers of boulders) }\end{array}$ & Dixon et al. (2006) \\
\hline
\end{tabular}


A key knowledge gap still hindering the success of stocking for many invertebrate taxa is the specific (micro)-habitat requirements of newly released juveniles. Finding the ideal habitat for releasing juveniles is more critical for slow-moving invertebrates than for fishes, which can easily move away from unfavourable habitats (Gillanders et al. 2003). Specific nursery habitats occupied most by wild juveniles would point to suitable habitats for release, but data on habitat preferences of wild juveniles are lacking for many invertebrate taxa (Conand 1989, Shiell 2004, Wolfe \& Byrne 2017). Equally, identified juvenile habitats might not be optimal, as they can be extremely limited in size, thus limiting area sizes for juvenile release, or may be determined by currentdriven larval distribution or stochastic events rather than specific environmental characteristics (Slater \& Jeffs 2010, Slater et al. 2010). Owing to ontogenetic habitat shifts, the habitats most preferred by adults are not reliable indicators of those required by juveniles (Ray \& Stoner 1995, Castell 1997, Childress \& Herrnkind 2001, Shiell 2004, Brownscombe et al. 2015, Wolfe \& Byrne 2017). Thus, research must use captive-bred juveniles to elucidate the microhabitats that should be targeted for their captive release (Munro \& Bell 1997).

Habitat variables that can act as predictors of marine invertebrate populations include depth, structural complexity, wave exposure and the composition of the benthos (Andréfouet et al. 2005, Dissanayake \& Stefansson 2012, Brownscombe et al. 2015). Studies assessing habitats for captive release of juvenile invertebrates have often used factorial experimental designs, where average survival and growth are compared between 2 or several habitat types (Table 1). Of 14 identified release studies on marine invertebrates that tested the effect of habitat, all except 2 used a factorial experimental approach (Table 1). However, marine habitats rarely exist homogeneously in space, so replicate sites chosen by researchers will rarely have the same suite of habitat features to assign them properly into discrete factors. Instead, multiple habitat features tend to vary across gradients, even at short spatial scales. For example, coastal seagrass beds and coral reef flats are a spatial mosaic of varying sediment types, species and coverage of plants, sessile habitat-forming fauna, depths and food resources. Moreover, the factorial approach to captive-release studies means that results could be ill-matched in other localities where the specific studied habitat types are not present (Purcell 2004b).

The alternative experimental approach examines the relationships between stocking responses (e.g. post-release survival and growth) and the various physical conditions that exist in likely habitats for captive release (Purcell \& Simutoga 2008, Hair et al. 2016). Responses will still be variable for any relationship with these features, since many spatially variable processes, like predation, can occur stochastically. However, a multiple-variable approach can provide better resolution for future captive-release programs because the habitat-related variations in responses are measured. This can allow a restocking program to better pinpoint specific habitat features to target for releasing captive-reared juveniles.

In this study, we applied a regression-based experimental field-release design, and we used gradient boosted regression tree (BRT) models to evaluate optimal habitat features for restocking and sea ranching of a tropical sea cucumber, the sandfish Holothuria scabra. Among tropical sea cucumber species, the sandfish commands the highest maximum value in the Asian seafood market (Purcell 2014) and is presently the most widely cultured tropical species for restocking and sea ranching (Purcell et al. 2012b). Wild populations of $H$. scabra are estimated to have declined by more than $90 \%$ in at least $50 \%$ of its range and are considered overexploited in at least $30 \%$ of its range; it is listed as Endangered on the IUCN Red List of Threatened Species (Hamel et al. 2013).

Tropical sea cucumbers in general occupy a wide variety of habitats, including coral reefs, coastal lagoons and seagrass beds (Conand 1989, Purcell et al. 2012a). Most of the commercially exploited species (Order: Aspidochirotida) are deposit feeders, consuming organically rich detritus mixed with inorganic sediments (Hammond 1983, Uthicke \& Karez 1999). Especially as juveniles, they are prone to predation by a range of predators, including sea stars, predatory gastropods, crabs, fishes and sea birds (Francour 1997, Purcell et al. 2016). Having few defences, many sea cucumbers display sheltering behaviours, such as hiding in crevices or burying in soft sediments. Little is known about the ecology of juvenile sea cucumbers in the wild, limiting the information for restocking programs. Juvenile sea cucumbers are rarely observed in nature (Shiell 2004, Eriksson et al. 2013). Earlier studies showed that juvenile sandfish can be found in shallow seagrass beds (Mercier et al. 2000), but the optimal habitat features within these macrohabitats were largely unstudied.

We aimed to determine the conditions for a range of key habitat features that would produce the best stocking success, measured by survival, growth and behavioural responses. Sandfish juveniles tend to 
bury most frequently during the late morning and afternoon, and burying has been speculated as a predatoravoidance strategy (Mercier et al. 1999, Purcell 2010), so we examined burial rates as the behavioural response to variation in habitats. Our findings reveal the relative importance of a number of key habitat features for restocking and sea ranching programs for this species and contribute to our knowledge of optimal habitats for captive release of these marine invertebrates.

\section{MATERIALS AND METHODS}

\section{Study site}

A sheltered, shallow bay at Ouano, within the large lagoon of New Caledonia's main island, La Grande Terre, was used for the juvenile release experiment (Fig. 1a). The bay is rimmed with mangrove trees and has no direct freshwater input from rivers. Fisherfolk in an adjacent settlement have reported a dramatic reduction in stocks of sandfish over the last $30 \mathrm{yr}$. The bay has extensive shallow (0 to $3 \mathrm{~m}$ ) seagrass meadows, with variations in depth, seagrass cover, substratum type (mostly a gradient from mud to coarse sand) and presence of macroalgae (e.g. Dictyota spp.) and other benthic biota. The dominant subtidal flora were the seagrasses Cymodocea serrulata, C. rotundata, Halodule uninervis, Halophila ovalis and Syringodium isoetifolium. Bidaily tidal fluxes are up to $1.5 \mathrm{~m}$ depth, and seawater visibility ranged from 0.5 to $3 \mathrm{~m}$.

\section{Experimental pens}

To isolate habitat-related effects and aid the recapture of juveniles, small sea pens without covers were constructed for the releases. A pilot study using small prototype pens within tanks at the hatchery confirmed that juveniles $>0.5 \mathrm{~g}$ body weight could not pass through mesh of $3 \mathrm{~mm}$ (data not shown). Several
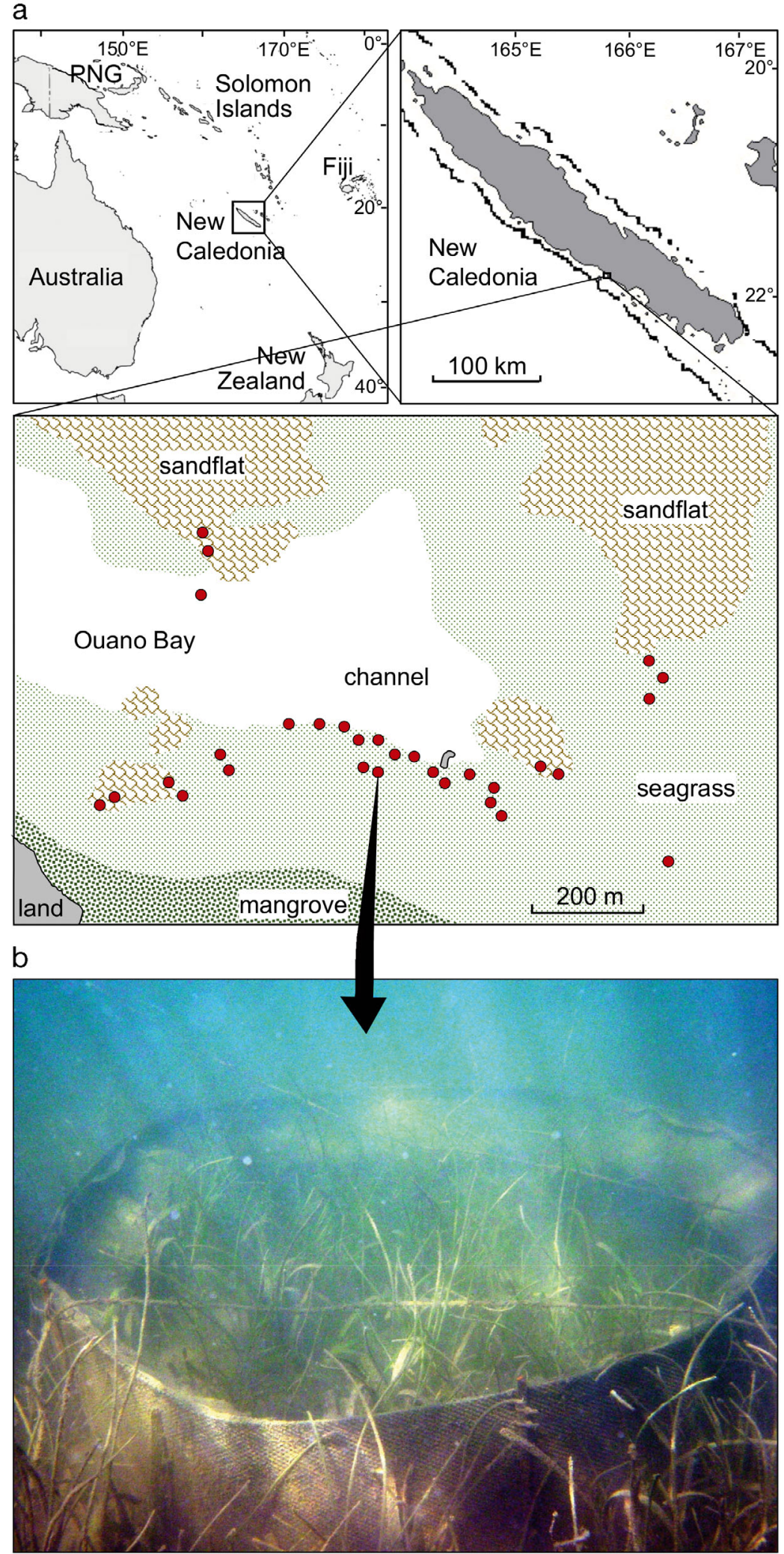

Fig. 1. Study site and layout of pens for experimental releases of juvenile sea cucumbers. (a) Map of release sites (red circles); (b) image of a pen and seagrass habitat 
trials of the very small pens (approx. $1000 \mathrm{~cm}^{2}$ ) also compared construction designs to limit the ability of juveniles to crawl over the top of the enclosure mesh. Escapement after 1 wk of 10 juveniles was compared among duplicate pens of 3 types: with the top edge bent inwards, with an inward-facing $1 \mathrm{~mm}$ net skirting at the top edge, and without modification to the top edge. Average escapement from pens with mesh skirting $(25 \%)$ was much lower than that from duplicate pens of the other types (60 and $70 \%$ ).

A total of 30 circular pens, comprising a mesh wall with no floor or roof, were used for the field experiment. The walls of the $1 \mathrm{~m}^{2}$ pens were $45 \mathrm{~cm}$ high, made of $3 \mathrm{~mm}$ black plastic mesh (Oyster Mesh, MOS Plastics) and supported upright by metal pickets. Each was fitted with a mesh skirt, $10 \mathrm{~cm}$ wide with $1 \mathrm{~mm}$ mesh, angled downwards into the pen by a cord and with the bottom edge frayed to reduce the surface area on which juveniles could attach (Fig. 1b). At a range of haphazardly chosen sites covering a broad range of habitat types, the pens were inserted $15 \mathrm{~cm}$ into the natural substratum such that the habitat inside the pen was left unchanged and in its natural state.

The seawater depth at each sea pen was measured to the nearest $0.1 \mathrm{~m}$ using a digital depth gauge and later corrected to zero tidal datum based on tide data and the time of measurement. To estimate the mean percentage cover of biotic and abiotic habitat characteristics, we distinguished 4 equal quadrants of the benthos in each enclosure. Within each quadrant, visual estimates were made of the percentage coverage of sand, rubble (coral rubble or shells $>2 \mathrm{~cm}$ ), rock (detached rocks $>2 \mathrm{~cm}$ ), sessile invertebrates, species-specific seagrass and macroalgae (Wilson et al. 2007), and we later used the averages of these 4 estimates for analyses. We constructed a penetrometer, comprising a weighted and graduated shaft within a tube affixed to a flat base set on the substratum, to give an index (in $\mathrm{cm}$ ) of sediment penetrability within each pen quadrant. A sediment sample of $\sim 50 \mathrm{ml}$, taken to a depth of $\sim 3 \mathrm{~cm}$ from the centre of each enclosure, was dried at $60^{\circ} \mathrm{C}$. Any animals $>3 \mathrm{~mm}$ within the samples were removed before splitting the samples randomly into 2 subsamples. One random subsample was analyzed for total organic carbon $(\mathrm{C})$ and nitrogen $(\mathrm{N})$ content using a Shimadzu TOC5000A-SSM analyzer and Antek 9000NS analyzer, respectively. The other sediment subsample was weighed to $\pm 0.001 \mathrm{~g}$, cleared of organic matter using household bleach following Purcell (1997) and then redried and reweighed to derive a metric of crude total organic matter. The cleared sediments were dry sieved through a series of mesh screens $(2000,1000,500,250,125$ and $63 \mu \mathrm{m})$, and grain fractions were weighed to calculate the mean grain size of the sediments following Dyer (1986).

\section{Hatchery production and release of juveniles}

Adult broodstock for breeding the juveniles were collected at Nepoui on the main island, La Grande Terre, which has sandfish stocks genetically similar to the release site at Ouano (Uthicke \& Purcell 2004). Adult spawning and juvenile rearing were done at a hatchery at Saint-Vincent, $28 \mathrm{~km}$ from Ouano. Breeding was conducted in December 2002, within the main reproductive season for this species (Conand 1993), and involved 40 adults, of which 4 females and 17 males spawned. Rearing of larvae and juveniles followed methods described by Battaglene (1999) and Agudo (2006). After initially rearing in tanks in the hatchery, juveniles were grown to the release size of 2-10 $\mathrm{g}$ in mesh bags with natural sediments on the floor of earthen seawater ponds. The juveniles were prepared for the field experiment in April 2003, when seawater temperatures were still warm $\left(27^{\circ} \mathrm{C}\right)$; sandfish are known to be active in New Caledonia at this time of the year (Purcell 2010). Thirty groups of 25 juveniles each were isolated into holding chambers at the hatchery overnight to allow them to defecate sediments before each group was drained for $1 \mathrm{~min}$ and weighed to the nearest $0.1 \mathrm{~g}$. The average individual weight, based on dividing group weight by number of individuals, was $3.26 \pm$ $0.17 \mathrm{~g}$ (mean $\pm \mathrm{SD}$ ).

The groups of juveniles were transported for $1 \mathrm{~h}$ to the study site in bags with seawater and oxygen (see Purcell et al. 2006), where they were assigned randomly to the experimental pens using random number tables. A diver released each group of juveniles from the bag onto the benthos in their assigned pens from $15: 40$ to $17: 40 h_{\text {; }}$ thus, they were contained in the bags for 1 to $3 \mathrm{~h}$.

At the end of the experiment, we collected all of the juveniles in the pens over $3 d$, so the groups of sandfish had 8, 9 or $10 \mathrm{~d}$ at liberty. All sampling was conducted between 10:00 and 16:00 $\mathrm{h}$, when daylight levels were high; this is outside of the hours when sandfish bury most. In New Caledonia, juvenile sandfish bury most frequently during the hours either side of sunrise (Purcell 2010). Sampling was carried out in 2 stages. First, the numbers of juveniles visible or partly visible on the benthos were counted as unburied and were collected and held separately. 
Second, because we had found in other studies (see Purcell 2010) that some juveniles could bury up to $3 \mathrm{~cm}$ into sediments, the remaining buried sea cucumbers were collected by hand, and all of the sediments and seagrass within the pens were removed to a depth of $5 \mathrm{~cm}$ by an air uplift suction sampler. The vacuumed contents passed into a mesh bag, where the silt and sand were strained out underwater, and the remaining contents were searched on board a boat for remaining juveniles. Some juveniles were found within the roots of seagrass. After counting all surviving sea cucumbers from each pen, the animals were placed into individual bags with oxygen and then taken to the hatchery, where each group was isolated into an empty holding chamber to defecate overnight before reweighing as described earlier in this subsection.

The natural abundance of sandfish juveniles was estimated by sampling 10 replicate quadrats within varied habitats at the study site. Quadrats $\left(1 \mathrm{~m}^{2}\right)$ were placed at $5 \mathrm{~m}$ distance from 10 randomly selected pens at random bearings. The sediments and flora were removed using air uplift suction, collecting all animals $>4 \mathrm{~mm}$ in size.

\section{Statistical analyses}

Survival rate of juveniles at the day of sampling was converted to a daily rate over the experimental period by taking the exponent of $-M$, where $M$ is the mortality rate calculated as the natural log of the proportionate survival divided by the number of days post-release. Average individual weights of sampled juvenile sea cucumbers minus the initial average individual starting weights gave the absolute growth, which was then expressed as a daily rate by dividing by the number of days at liberty. The proportion of animals unburied out of the total number sampled in each pen was the burial rate. No wild sandfish were found in the natural habitat outside of the pens.

Environmental drivers of survival, growth and burial rates of the juvenile sandfish were explored via gradient BRT models (Ridgeway 2017). BRT models are typically encouraged to learn thoroughly by constructing very large numbers of small regression trees, training each tree on a random subset of the residuals from the preceding tree and shrinking the contribution of each tree (De'ath 2007, Elith et al. 2008, Hastie et al. 2011). Overfitting can be countered through one of a number of regularization techniques (such as cross-validation) that serve to strike a balance between predictive performance and model fit (Hastie et al. 2011). Unlike linear models, BRTs are robust to multicollinearity and non-linearity and are not reduced to low-dimensional approximations of the system complexity. Therefore, BRTs are well suited to exploring relative impacts of a large pool of complex predictors.

A total of 5000 trees were fit to an interaction depth of 5 , bag fraction of 0.5 and shrinkage rate of 0.001 . The optimal number of boosting iterations was determined by the out-of-bag method (Breiman et al. 1984). The relative importance of each predictor was calculated as the frequency of splits involving each variable weighted by the associated square improvement in the model averaged over all trees and scaled out of 100 such that larger values signify stronger influence. Uncertainty in partial effects and relative importance estimates was incorporated by bootstrapping (sampling with replacement) each BRT 100 times. For each bootstrap BRT, parameter values associated with maximizing the response were estimated by optimizing the predicted response across the domain of all predictors. Optimization was based on a modification of simulated annealing (Belisle 1992) with 10000 maximum iterations, as this approach is capable of optimizing non-differential functions. Within each bootstrap BRT, for both the full model as well as each of the predictors therein, quasi- $\mathrm{R}^{2}$ values were also calculated according to:

$$
\text { quasi } \mathrm{R}^{2}=1-\frac{\sum\left(O_{i}-F_{i}\right)^{2}}{\sum\left(O_{i}-\hat{O}_{i}\right)^{2}}
$$

where $O_{i}$ and $F_{i}$ are the $i$ th observed and fitted response values, respectively. In the case of individual predictor $\mathrm{R}^{2}$ calculations, $F_{i}$ values are the partial fitted values (values predicted when all other predictors are held constant at their respective means). All BRT models were fit via the gbm package (Ridgeway 2017) within the R statistical and graphical environment (R Development Core Team 2010).

The relationship between survival and burial rates of the groups of sea cucumber juveniles was examined by non-linear regression modelling. The best fit of 298 standard equations fitted using DataFit software was selected using Akaike's information criterion.

\section{RESULTS}

\section{Survival}

In 3 pens, nearly all of the juvenile sandfish were absent at the end of the experiment, presumably owing mostly to predation (survival rates 0 to $8 \%$ ). 
Potential predators seen in the pens during the week-long experiment included tetraodontid fishes, crabs and stomatopods. Upon completion of the experiment and sampling of infauna, we also found predatory crabs and predatory sea stars that had been buried or partially buried in the sediments. In the sole pen with zero survival, we found a large portunid crab. In total, we found 3 damaged (cuts to body wall) sandfish juveniles, which were counted as surviving, and 4 dead sandfish (body severely lacerated and lifeless). The surviving buried juveniles were mostly found in the upper 0 to $3 \mathrm{~cm}$ of sediments.

The BRT models found that the best predictors for the survival rate were seagrass cover and seawater depth (Table 2). These 2 variables were the only ones with median values of importance above the threshold of expected value given the number of predictors (Fig. 2) but accounted for just $17 \%$ of variation in survival rates. Survival was highest where seagrass cover was within the range of 21 to $69 \%$ and was optimal at $42 \%\left(\mathrm{R}^{2}=0.08\right.$, Fig. 2, Table $\mathrm{S} 1$ in the Supplement at www.int-res.com/articles/suppl/m588 p085_supp.pdf). Survival was still relatively high as seagrass cover increased above the optimum. At low seagrass cover $(<20 \%)$, survival was poor.

Survival was also best at the shallowest depths, deteriorating by approximately $25 \%$ at $3 \mathrm{~m}$ and deeper $\left(R^{2}=0.09\right)$. Survival was highest at around $1.1 \mathrm{~m}$ depth. When all predictors were optimised, the daily survival rate was almost $97 \%$.

Almost all other variables were of limited importance to the survival of juvenile sandfish $\left(R^{2}\right.$ values
$<0.02$ ) and had low variability (Fig. 2c, Fig. S1 in the Supplement). Organic C content (optimal for survival at an intermediate level of $1.55 \%$ organic C) and weight at release (showing the best survival at the relatively large size of $3.3 \mathrm{~g}$ ) were slightly more important $\left(R^{2}=0.4\right)$ but were not significant predictors of survival.

\section{Growth}

The average weight of juveniles at release, seagrass cover and sediment grain size were the 3 best predictors for the growth rates of sandfish (Fig. 3). These 3 variables together accounted for $29 \%$ of the variation in growth rates among sample groups (Table 2). Sandfish from groups with lesser average release weights grew fastest. Highest growth rates occurred where seagrass cover was around $34 \%$ (Table 2), with a confidence range of 16 to $48 \%$ (Table S1). The optimal average grain size of sediments for sandfish growth rates was $135.2 \mu \mathrm{m}$, corresponding to fine sand. Growth rates were negligible for groups on very fine sand and silt (grain size $<100 \mu \mathrm{m}$ ) and also declined slightly when average grain size was above $300 \mu \mathrm{m}$, i.e. medium and coarse sand (Fig. $3, \mathrm{R}^{2}=0.06$ ). With all predictor variables optimized, the maximum growth rate was $0.07 \mathrm{~g} \mathrm{~d}^{-1}$, equating to a relative weight gain of approximately $1.7 \% \mathrm{~d}^{-1}$.

Depth and the proportion of organic $\mathrm{C}$ in sediments influenced growth somewhat, but neither was a significant predictor (Fig. 3). The number of sessile

Table 2. Parameter estimates optimised for maximum growth, survival and burial rates. Predictors that performed best (i.e. they were disproportionately represented in trees) are highlighted in bold. Maximum survival rate at optimization estimated to be $0.97 \mathrm{~d}^{-1}$ (95\% CI: 0.99 to 1.11$)$, maximum growth rate $0.07 \mathrm{~g}$ ind..$^{-1} \mathrm{~d}^{-1}$ (0.07 to 0.12$)$ and maximum burial rate $67.8 \%(67.8$ to 80.7 ). Only the optimum estimate is included here; this table is presented in its full form in Table S1 in the Supplement at www.int-res.com/articles/suppl/m588p085_supp.pdf

\begin{tabular}{|c|c|c|c|c|c|c|}
\hline \multirow{2}{*}{ Predictors } & \multicolumn{2}{|c|}{$\longrightarrow$ Survival } & \multicolumn{2}{|c|}{ Growth rate -} & \multicolumn{2}{|l|}{- Burying -} \\
\hline & Optimum estimate & $\mathrm{R}^{2}$ & Optimum estimate & $\mathrm{R}^{2}$ & Optimum estimate & $\mathrm{R}^{2}$ \\
\hline Weight at release (g) & 3.3 & 0.04 & 3.2 & 0.13 & 3.3 & 0.05 \\
\hline Seagrass cover $(\%)$ & 42 & 0.08 & 34 & 0.10 & 52 & 0.06 \\
\hline Organic carbon content (\%) & 1.6 & 0.04 & 1.3 & 0.06 & 1.9 & 0.23 \\
\hline Grain size $(\mu \mathrm{m})$ & 189 & 0.02 & 135 & 0.06 & 152 & 0.06 \\
\hline Crude organic matter (\%) & 7.6 & 0.01 & 6.9 & 0.05 & 7.5 & 0.04 \\
\hline Depth (m) & 1.1 & 0.09 & 0.8 & 0.04 & 0.3 & 0.16 \\
\hline Penetrability (cm) & 9 & 0.03 & 9 & 0.05 & 10 & 0.03 \\
\hline Macroalgae cover (\%) & 7.7 & 0.01 & 1.7 & 0.03 & 2.3 & 0.08 \\
\hline Organic nitrogen content (\%) & 0.1 & 0.01 & 0.2 & 0.02 & 0.2 & 0.08 \\
\hline Shellfish abundance (ind. $\mathrm{m}^{-2}$ ) & 2.2 & 0 & 1.1 & 0.01 & 2.0 & 0.01 \\
\hline Rock/rubble cover (\%) & 7.6 & 0.02 & 5.9 & 0.02 & 3.6 & 0.01 \\
\hline Sessile invertebrate cover (\%) & 2.6 & 0 & 1.3 & 0.01 & 2.4 & 0 \\
\hline
\end{tabular}



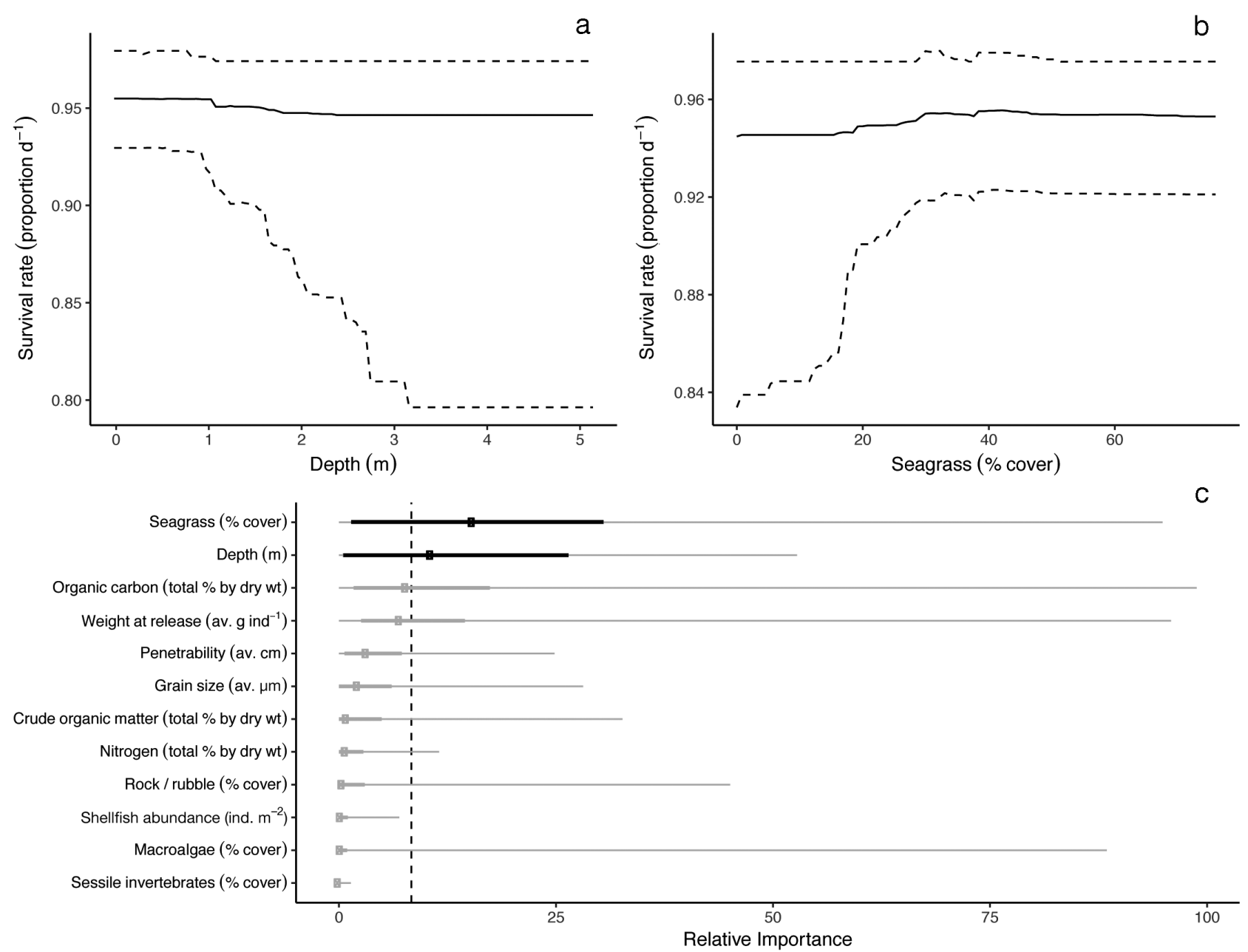

Fig. 2. (a,b) Bootstrap boosted regression tree partial effects plots relating to survival rate against significant predictor variables and (c) associated relative importance plot. (a,b) Solid and dashed lines represent median and lower/upper $95 \%$ quantiles, respectively. (c) Dots represent medians, and thick and thin bars represent 50 and $95 \%$ quantiles, respectively. The vertical dashed line represents the threshold (100/12) above which predictors are disproportionately represented in trees, and dots and bars are shaded according to whether they exceed this threshold (black) or not (grey)

invertebrates and shellfish (e.g. Anadara sp.) in the pens, the cover of rock and rubble and the $\mathrm{N}$ content of the sediments were among the predictors least affecting growth rates (Fig. S2).

\section{Burying behaviour}

Habitat features that influenced the frequency of burial by the juvenile sea cucumbers were the organic $\mathrm{C}$ content in the sediments and seawater depth (Fig. 4, Table 2). These 2 variables explained $39 \%$ of the variation in burial frequency among replicate groups of juveniles. Unlike the relatively small proportion of variation explained by predictor variables for growth and survival, all habitat variables com- bined explained most $(81 \%)$ of the total variation in burial rates.

Burial rates were highest where sediments had relatively high organic $\mathrm{C}$ content of $1.9 \%$ organic $\mathrm{C}$ and above $\left(R^{2}=0.23\right)$. Burying behaviour was also most pronounced at shallow depths of around $0.3 \mathrm{~m}$, with a confidence range of 0.1 to $0.8 \mathrm{~m}$ (Table S1). Burying behaviour declined by one-quarter at $1.5 \mathrm{~m}$ or deeper $\left(\mathrm{R}^{2}=0.16\right)$. In optimal conditions, $68 \%$ of surviving juveniles exhibited burying behaviour during daytime observations.

Juveniles tended to bury less frequently in silty sediments (average grain size $<100 \mu \mathrm{m})\left(\mathrm{R}^{2}=0.06\right)$, but this variable was statistically non-significant. Interestingly, other sediment characteristics that could conceivably affect burying were less impor- 

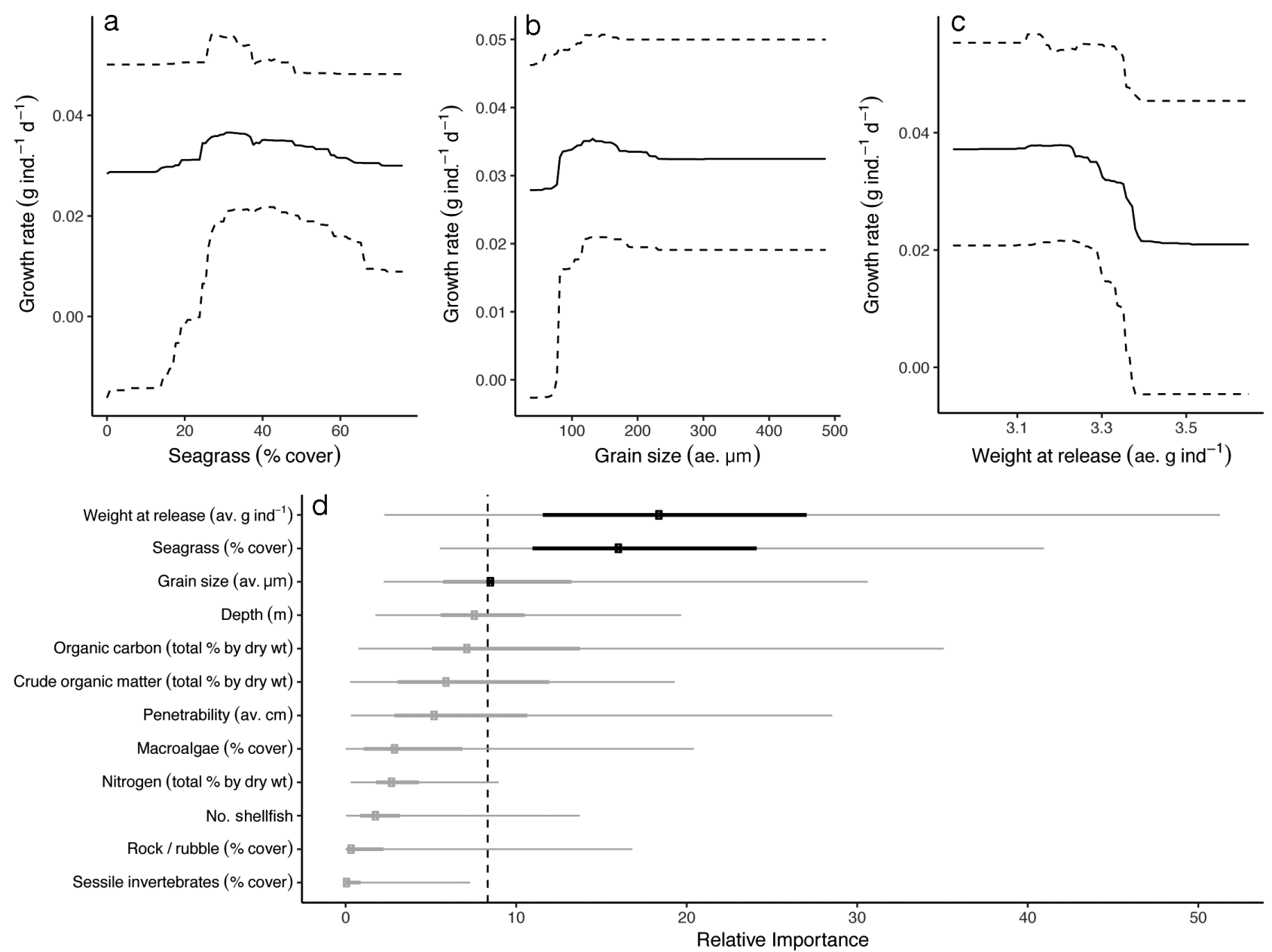

Fig. 3. $(a, b, c)$ Bootstrap boosted regression tree partial effects plots relating to growth rate against significant predictor variables and (d) associated relative importance plot. (a,b,c) Solid and dashed lines represent median and lower/upper $95 \%$ quantiles, respectively. (d) Dots represent medians, and thick and thin bars represent 50 and $95 \%$ quantiles, respectively. The vertical dashed line represents the threshold (100/12) above which predictors are disproportionately represented in trees, and dots and bars are shaded according to whether they exceed this threshold (black) or not (grey)

tant, including sediment penetrability $\left(\mathrm{R}^{2}=0.03\right)$ and rock or rubble cover $\left(\mathrm{R}^{2}=0.01\right.$; Fig. S3).

\section{Cumulative and additive effects}

Some habitat attributes that had the strongest influence on survival, growth and burying behavior of juvenile sandfish (seagrass cover, organic $\mathrm{C}$ and $\mathrm{N})$ were clearly prevalent at the shallowest depth (Fig. 5). Habitats shallower than $2 \mathrm{~m}$ exhibited a range of seagrass and sediment nutrient values; but below $2 \mathrm{~m}$ depth there was little seagrass, and the distribution of organic $\mathrm{C}$ and $\mathrm{N}$ content values tapered towards lower or intermediate levels of 1.0 and $0.14 \%$, respectively. The relationship between burial and survival was strong $\left(\mathrm{R}^{2}=0.73\right)$ and non-linear (Fig. 6). The proportion of individual sandfish surviving per day declined dramatically when burial rates were lower.

\section{Natural juvenile density}

We found zero wild sandfish in the 10 randomly sampled quadrats in natural habitats near the pens. However, through the air uplift destructive sampling, we recovered 1 wild juvenile sandfish in one of the experimental pens that was too small $(<1 \mathrm{~g})$ to have been one of the juveniles we released. That animal was not included in data for that replicate pen but confirms that wild juvenile sandfish were 

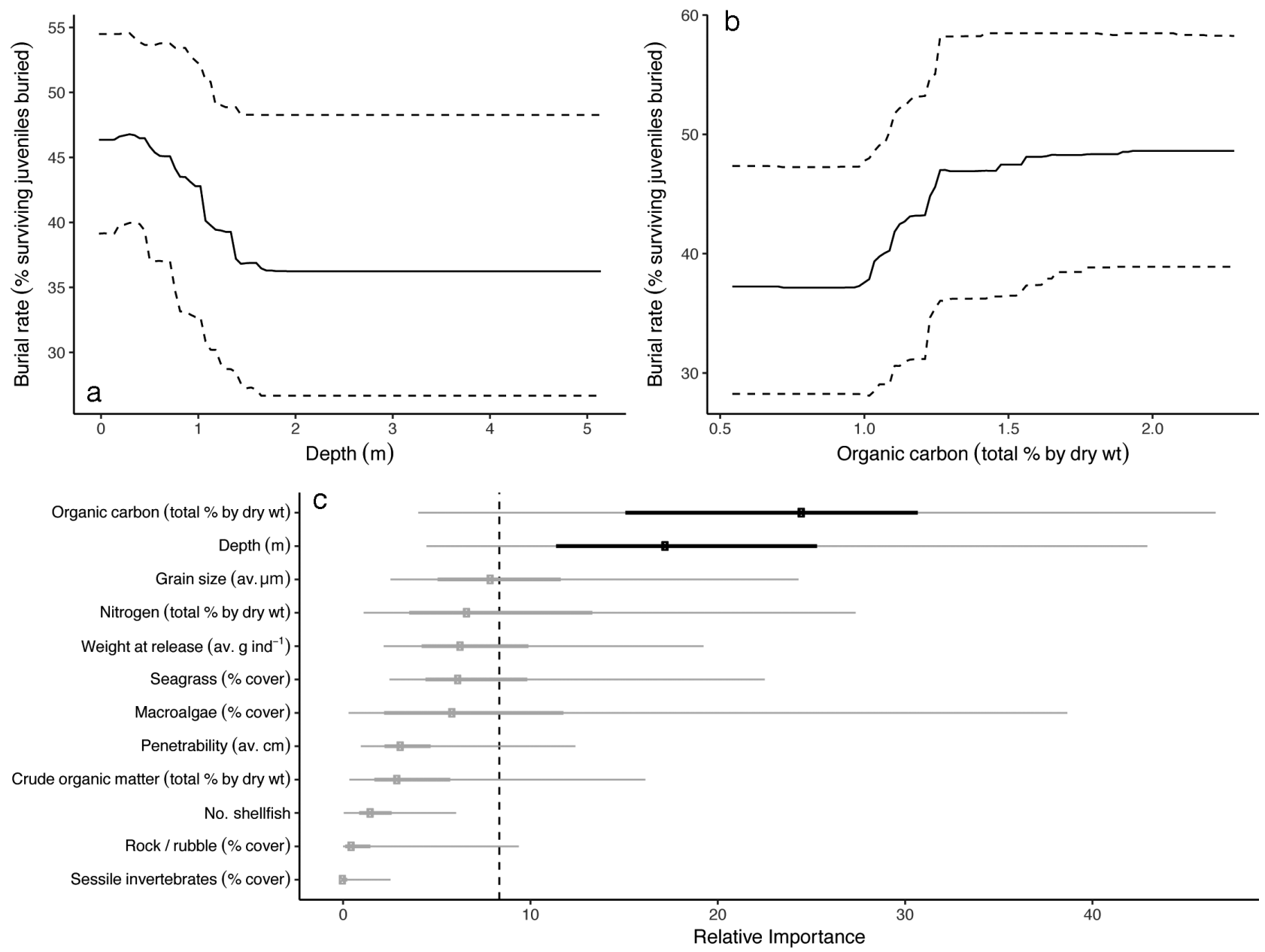

Fig. 4. (a,b) Bootstrap boosted regression tree partial effects plots relating to burial rate against significant predictor variables and $(\mathrm{c})$ associated relative importance plot. $(\mathrm{a}, \mathrm{b})$ Solid and dashed lines represent median and lower/upper $95 \%$ quantiles, respectively. (c) Dots represent medians, and thick and thin bars represent 50 and $95 \%$ quantiles, respectively. The vertical dashed line represents the threshold (100/12) above which predictors are disproportionately represented in trees, and dots and bars are shaded according to whether they exceed this threshold (black) or not (grey)

present. However, densities were low enough to have negligible effects on our results from experimental pens.

\section{DISCUSSION}

Juvenile invertebrates reared for purposes of restocking, stock enhancement or sea ranching must be released into habitats that will provide shelter, conditions for natural behaviours and the necessary matter for growth and nourishment. The success of restocking and sea ranching depends on knowledge about the species' ecology and nursery habitat and the survival of cultured juveniles in the wild (Bell et al. 2005). This study distinguished between a number of key habitat variables and revealed which among them were the most important for survival, growth and a key behaviour affecting stocking success of Holothuria scabra. While certain habitat features were linked to both optimal growth and survival, the relationships can be nonlinear and variables might be more important for one response but not another. This implies that habitat selection by sea cucumbers at early life history stages is finely tuned, based on parameters that strike a balance between survival, growth and behaviours.

Importantly, while habitat features had a large effect on burying behaviours during daylight hours, they did not explain a large portion of variation in survival. Sandfish juveniles are known to bury most frequently before sunrise and in the early morning, 


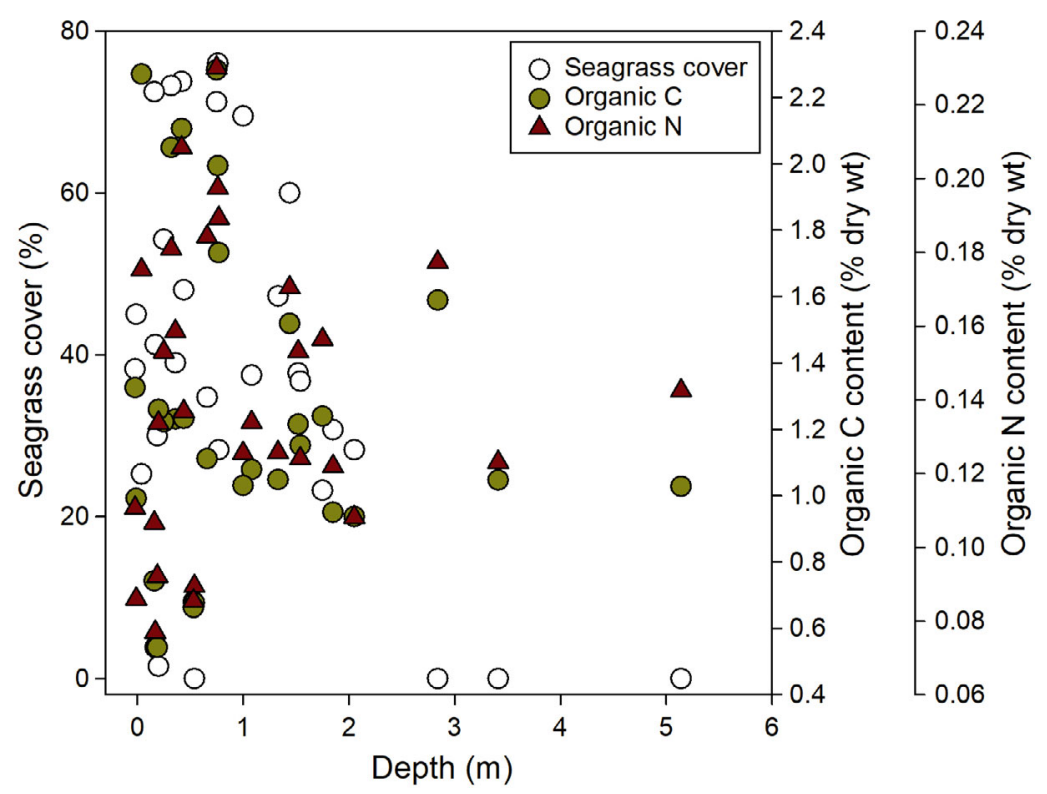

Fig. 5. Distribution of seagrass cover, organic $\mathrm{C}$ and $\mathrm{N}$ content across the depth range of the study. For each variable type, each data point is the habitat measure in a replicate experimental pen

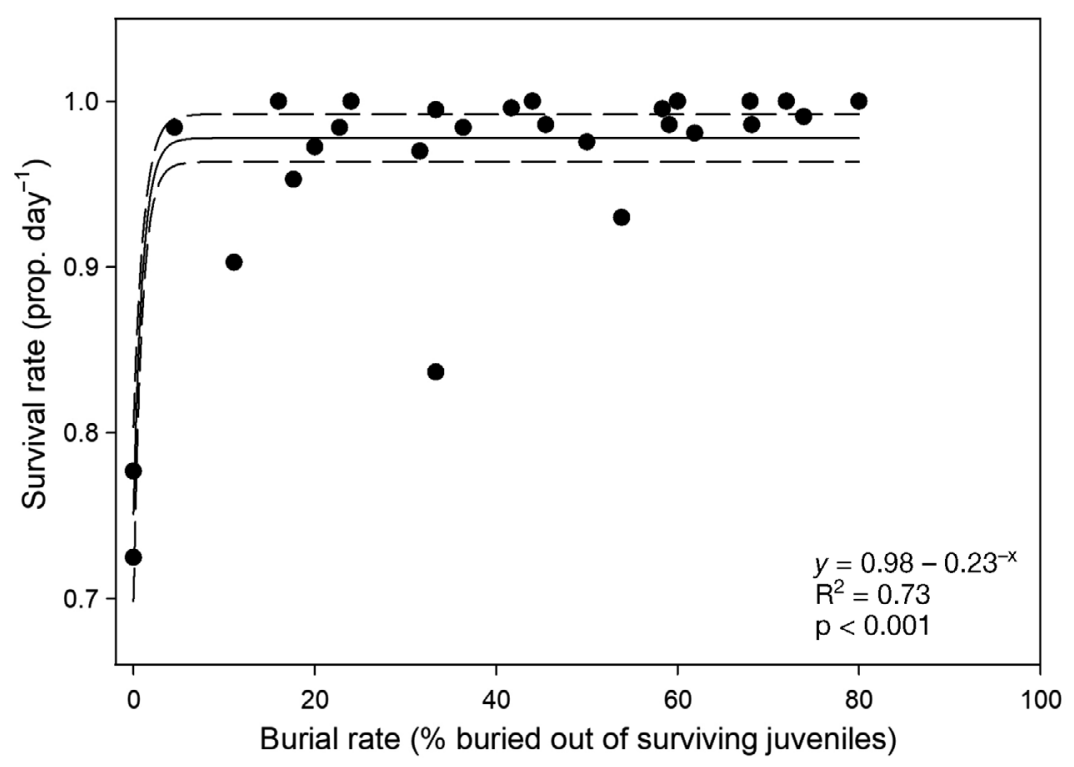

Fig. 6. Relationship between burial rates and survival of juvenile sandfish. The best fit for the relationship was an exponential rise to maximum regression with 2 estimated parameters. Dashed lines represent $95 \%$ CI

events are still likely to be patchy and unpredictable (Slater \& Jeffs 2010, Slater et al. 2010). This suggests that wide dispersal of recruits across suitable habitats is a strategy that would allow at least some individuals of certain marine invertebrates to survive beyond early life history stages. Therefore, releases of juvenile invertebrates should be dispersed over numerous areas possessing the optimal nursery habitat features to spread risks of stochastic mortalities.

Key habitat characteristics critical to the survival, growth and daytime burying behaviour of juvenile sandfish released into the wild were relatively shallow depth $(0.3$ to $1.5 \mathrm{~m})$, intermediate seagrass cover (30 to $50 \%)$, fine sand grains $(\sim 130 \mu \mathrm{m})$ and high organic C content ( $>1.9 \%$ ) of the sediments. Factorial designs are likely to miss the optimum range of influential features that exist within habitat types. For example, a regression experimental design in this study provided a means for examining responses across a wide gradient of seagrass cover. With our BRT modelling approach, we refine the understanding of the relationship between habitat variables and survival and growth of this species and offer the first field test of the effects of habitat on its behaviour.

\section{Survival}

Habitat influences the survival of juvenile invertebrates in captive release programs through variables such as food availability, adequate biophysical conditions and shelter from predation (Purcell 2004a, Ya-

although burial is rarely complete across all animals in the population (Mercier et al. 1999, Purcell 2010). Our observations of burial rates were made in the late morning and afternoon, when fewer animals would be expected to bury. The relationships between burying frequency and both habitat and survival indicate that survival can be optimized by selecting optimal nursery habitats, but mortality mana et al. 2006, Bartley \& Bell 2008, Hines et al. 2008). We found that relatively shallow depths and intermediate seagrass cover improved survivorship of juvenile sandfish. In this turbid environment, shallow water allows the most light penetration to facilitate seagrass growth and microalgal production within the sediment, and shallows may also be a refuge from predation (Ruiz et al. 1993, Paterson \& 
Whitfield 2000). Intermediate seagrass cover was best for survival, perhaps because juveniles gain some cover from predation but are still able to bury and feed on sediments among seagrass plants, which could both be more difficult where seagrasses are dense (Mercier et al. 2000).

With all habitat variables optimized, survival rate $\left(97 \% \mathrm{~d}^{-1}\right)$ was commensurate with initial survival rates in other studies on released sandfish (Lavitra et al. 2010, Hair et al. 2016, Juinio-Meñez et al. 2017), considering also that survival rates improve as marine animals grow (Heasman 2006). Mortality tends to be highest soon after release (Tanaka 2000, Heasman 2006, Okuzawa et al. 2008), and a study releasing sea cucumbers into suboptimal habitats reported survival rates of just $30 \%$ in $3 \mathrm{~d}$ (Dance et al. 2003). This suggests that research effort and cost of determining optimal nursery habitats will pay off in the longer term by enhancing survival.

\section{Growth}

While maximum survival is desirable, optimizing growth rates is also essential for captive release programs (Purcell \& Simutoga 2008). In the long term, habitats that provide for fast growth rates will also increase survival rates for invertebrate species that gain a predation refuge at a certain size (Hines et al. 2008, but see Okuzawa et al. 2008).

Usually, higher growth rates are related to higher food availability or quality (e.g. Young et al. 2008). Other studies have found variable effects of sediment structure and quality on survival or growth rates of juvenile sandfish (Lavitra et al. 2010, Tsiresy et al. 2011, Altamirano et al. 2017). Factors affecting the ability to forage and shelter (i.e. intermediate seagrass cover and fine sand sediments) might be more important for growth of these juvenile invertebrates than the nutrient (i.e. N) content of sediments. The weight at release of the juveniles will also influence growth rates over a short timeframe. A relative growth rate of $1.7 \% \mathrm{~d}^{-1}$ in this study is comparable to that found for juvenile sandfish in other studies (Lavitra et al. 2010, Tsiresy et al. 2011, Watanabe et al. 2014, Altamirano et al. 2017). The higher growth rates for smaller juveniles reveals an often overlooked element of captive release programs - the ability of captive-released juveniles to show compensatory growth during the initial release phase (Altamirano et al. 2017).

Our study found that similar habitat values could optimize both growth and survival, such as approxi- mately 30 to $45 \%$ seagrass cover. In this case, intermediate seagrass cover probably still allowed ample foraging on sediments. Juveniles might expend less energy avoiding predators than at greater depth where sediments contained moderate amounts of $\mathrm{C}$ and $\mathrm{N}$ but where sparse seagrass afforded little protection from predators (Fig. 5).

\section{Behaviour}

Burial in sediments has been speculated as a potential predator avoidance behaviour in this and other invertebrate species (Wilson 1990, Rochette et al. 1999, Purcell 2010). Empirical evidence is lacking to link burying behaviour to reduced predation; however, it has been directly linked to stress reduction and increased growth and survival in sea cucumbers (Robinson et al. 2013). Here, we show that sandfish groups with higher burying rates during daytime also had higher survival rates (Fig. 6). Therefore, restocking or sea ranching programs should take into account habitat characteristics (e.g. fine sand and relatively high amounts of fine plant matter in sediments) that facilitate this behaviour (Hines et al. 2008, Young et al. 2008, Purcell 2010).

Some restocking programs acknowledge the importance of behaviour and apply behavioural conditioning techniques (e.g. for predator avoidance and food search capability) before release into the wild (Schiel \& Welden 1987, Okuzawa et al. 2008). Sandfish can be reared on sand in the weeks prior to release in the wild to encourage the development of burying behaviour (Purcell 2010, Juinio-Meñez et al. 2012). Similar training has been advocated prior to the captive release of juveniles of other invertebrate species, such as lobsters and queen conch (Brown \& Day 2002, Delgado et al. 2002, Agnalt et al. 2017).

At shallow depths, the juveniles buried more frequently and survived better, but long periods of burial might be at a cost to growth rates. Our analyses found that habitat variables explained a much higher proportion of the variation in the proportion of juveniles buried during the daytime sampling than for growth and survival. This finding implies that, in addition to behavioural conditioning in the hatchery, predator avoidance behaviours can be largely promoted by characteristics of the release habitat.

Burial rates in sandfish were also highest at intermediate $\mathrm{C}$ content in the sediment. The biology and ecology (in this case, behaviour) of sea cucumbers can indeed be affected by the organic content of sediments (Hamel et al. 2001, Hair et al. 2016). Sandfish 
do not feed when they are buried (Mercier et al. 2000), but higher content of detrital plant matter in the sediments could mean that the sandfish are spending less time gathering nutrition, leaving more time for burial.

\section{Further considerations}

Captive-bred juveniles can have different morphology, behaviour or habitat preferences to wild conspecifics (Purcell 2004b, Young et al. 2008). Nonetheless, captive release experiments offer a means to explore relationships of early life stages with habitat variables that might otherwise be impossible for species with highly elusive juveniles, such as sea cucumbers (Shiell 2004).

For the purpose of the experiment, we used an extraordinarily high density of release. Although Purcell \& Simutoga (2008) found no difference in survival among release densities of $0.5,1$ and 3 ind. $\mathrm{m}^{-2}$, much higher densities could induce higher mortality rates due to foraging behaviour of predators (Eriksson et al. 2013, Wolfe \& Byrne 2017). The survival rates in this study may therefore have been compromised to some extent by the high density of release.

Stocking density and habitat interact to yield a certain carrying capacity (Hines et al. 2008); for example, in Japan, there was a strong relationship between the type of macroalgal habitat and the carrying capacity of abalone (Hamasaki \& Kitada 2008). Although density dependence and ontogenetic habitat shifts were not specifically explored in this study, these variables can also interact with habitat to affect survival, growth and behaviour in marine invertebrates (Heasman 2006, Hamasaki \& Kitada 2008, Hines et al. 2008, Purcell \& Simutoga 2008, Brownscombe et al. 2015, Altamirano et al. 2017). We found that sandfish survived best in shallow subtidal seagrass beds and probably move to deeper waters as they grow larger, as observed for other sea cucumber species (Tanaka 2000, Yamana et al. 2006, Eriksson et al. 2013, Wolfe \& Byrne 2017). Releasing invertebrate species with clear ontogenetic habitat shifts will require the selection of initial release habitats that are close to habitats suitable for later life stages (Castell 1997, Gillanders et al. 2003, Hines et al. 2008).

Acknowledgements. We thank the staff of WorldFish Center and the Secretariat of the Pacific Community for their administrative support. Helpful comments were given by N. Andrew, J. Bell, W. Nash and S. Uthicke. We thank N. Agudo, P. Blazer, B. Blockmans, J. Le Dreau and M.
Simutoga for their helpful assistance. The project was funded by the Australian Centre for International Agricultural Research (ACIAR) through project FIS/1999/025, the 3 provinces of New Caledonia and the government of France.

\section{LITERATURE CITED}

Agnalt AL, Grefsrud ES, Farestveit E, Jorstad KE (2017) Training camp - a way to improve survival in European lobster juveniles? Fish Res 186:531-537

Agudo N (2006) Sandfish hatchery techniques. Australian Centre for International Agricultural Research (ACIAR), Secretariat of the Pacific Community (SPC) and WorldFish Centre, Noumea

Altamirano JP, Recente CP, Rodriguez JC Jr (2017) Substrate preference for burying and feeding of sandfish Holothuria scabra juveniles. Fish Res 186:514-523

Andréfouet S, Gilbert A, Yan L, Remoissenet G, Payri C, Chancerelle Y (2005) The remarkable population size of the endangered clam Tridacna maxima assessed in Fangatau Atoll (eastern Tuamotu, French Polynesia) using in situ and remote sensing data. ICES J Mar Sci 62: 1037-1048

Arnold WS (2008) Application of larval release for restocking and stock enhancement of coastal marine bivalve populations. Rev Fish Sci 16:65-71

Bannister RCA, Addison JT (1998) Enhancing lobster stocks: a review of recent European methods, results and future prospects. Bull Mar Sci 62:369-387

Bartley D, Bell JD (2008) Restocking, stock enhancement and sea ranching: arenas of progress. Rev Fish Sci 16: 357-365

Battaglene SC (1999) Culture of tropical sea cucumbers for the purposes of stock restoration and enhancement. Naga, ICLARM Q 22:4-11

Battaglene SC, Bell JD (2008) The restocking of sea cucumbers in the Pacific Islands. In: Bartley DM, Leber KM (eds) Marine ranching. FAO Fish Tech Pap 429. FAO, Rome, p 109-132

Beal BF, Kraus MG (2002) Interactive effects of initial size, stocking density, and type of predator deterrent netting on survival and growth of cultured juveniles of the softshell clam, Mya arenaria L., in eastern Maine. Aquaculture 208:81-111

* Behringer DC, Butler MJ IV, Herrnkind WF, Hunt JH, Acosta CA, Sharp WC (2009) Is seagrass an important nursery habitat for the Caribbean spiny lobster, Panulirus argus, in Florida? NZ J Mar Freshw Res 43:327-337

Bélisle CJP (1992) Convergence theorems for a class of simulated annealing algorithms on $\mathrm{R}^{d}$. J Appl Probab 29: 885-895

*Bell JD, Rothlisberg PC, Munro JL, Loneragan NR, Nash WJ, Ward RD, Andrew NL (eds) (2005) Restocking and stock enhancement of marine invertebrate fisheries. Adv Mar Biol 49:1-374

Bell JD, Leber KM, Blankenship HL, Loneragan NR, Masuda R (2008) A new era for restocking, stock enhancement and sea ranching of coastal fisheries resources. Rev Fish Sci 16:1-9

Booth JD, Ayers D (2005) Characterising shelter preferences in captive juvenile Jasus edwardsii (Palinuridae). NZ J Mar Freshw Res 39:373-382

Breiman L, Friedman JH, Olshen RA, Stone CJ (1984) Classification and regression trees. Wadsworth, Belmont, CA 
Brown C, Day RW (2002) The future of stock enhancements: lessons for hatchery practice from conservation biology. Fish Fish 3:79-94

*Bownscombe JW, Wilson ADM, Samson E, Nowell L, Cooke SJ, Danylchuk AJ (2015) Individual differences in activity and habitat selection of juvenile queen conch evaluated using acceleration biologgers. Endang Species Res 27:181-188

* Castell L (1997) Population studies of juvenile Trochus niloticus on a reef flat on the north-eastern Queensland coast, Australia. Mar Freshw Res 48:211-217

Castell LL, Naviti W, Nguyen F (1996) Detectability of cryptic juvenile Trochus niloticus Linnaeus in stock enhancement experiments. Aquaculture 144:91-101

Childress MJ, Herrnkind WF (2001) Influence of conspecifics on the ontogenetic habitat shift of juvenile Caribbean spiny lobsters. Mar Freshw Res 52:1077-1084

Conand C (1989) Les holothuries aspidochirotes du lagon de Nouvelle-Calédonie: biologie, écologie et exploitation. Etudes et Thèses, ORSTOM, Paris

Conand C (1993) Reproductive biology of the holothurians from the major communities of the New Caledonian lagoon. Mar Biol 116:439-450

Crowe TP, Lee CL, McGuinness KA, Amos MJ and others (2002) Experimental evaluation of the use of hatcheryreared juveniles to enhance stocks of the topshell Trochus niloticus in Australia, Indonesia and Vanuatu. Aquaculture 206:175-197

Dance SK, Lane I, Bell JD (2003) Variation in short-term survival of cultured sandfish (Holothuria scabra) released in mangrove-seagrass and coral reef flat habitats in Solomon Islands. Aquaculture 220:495-505

Davis JLD, Eckert-Mills MG, Young-Williams AC, Hines $\mathrm{AH}$, Zohar Y (2005) Morphological conditioning of a hatchery-raised invertebrate, Callinectes sapidus, to improve field survivorship after release. Aquaculture 243: $147-158$

De'ath G (2007) Boosted trees for ecological modeling and prediction. Ecology 88:243-251

Delgado GA, Glazer RA, Stewart NJ (2002) Predatorinduced behavioural and morphological plasticity in the tropical marine gastropod Strombus gigas. Biol Bull 203: 112-120

Dissanayake DCT, Stefansson G (2012) Habitat preference of sea cucumbers: Holothuria atra and Holothuria edulis in the coastal waters of Sri Lanka. J Mar Biol Assoc UK 92:581-593

Dixon CD, Day RW, Huchette SMH, Shepherd SA (2006) Successful seeding of hatchery-produced juvenile greenlip abalone to restore wild stocks. Fish Res 78:179-185

Dyer KR (1986) Coastal and estuarine sediment dynamics. Wiley, Chichester

Elith J, Leathwick JR, Hastie T (2008) A working guide to boosted regression trees. J Anim Ecol 77:802-813

Eriksson H, Thorne BV, Byrne M (2013) Population metrics in protected commercial sea cucumber populations (curryfish: Stichopus herrmanni) on One Tree Reef, Great Barrier Reef. Mar Ecol Prog Ser 473:225-234

Francour P (1997) Predation on holothurians: a literature review. Invertebr Biol 116:52-60

* Gillanders BM, Able KW, Brown JA, Eggleston DB, Sheridan PF (2003) Evidence of connectivity between juvenile and adult habitats for mobile marine fauna: an important component of nurseries. Mar Ecol Prog Ser 247:281-295

Gomez ED, Mingoa-Licuanan SS (2006) Achievements and lessons learned in restocking giant clams in the Philippines. Fish Res 80:46-52

* Gristina M, Fiorentino F, Garofalo G, Badalamenti F (2009) Shelter preference in captive juveniles of European spiny lobster Palinurus elephas (Fabricius, 1787). Mar Biol 156:2097-2105

* Hair C, Mills DJ, McIntyre R, Southgate PC (2016) Optimising methods for community-based sea cucumber ranching: experimental releases of cultured juvenile Holothuria scabra into seagrass meadows in Papua New Guinea. Aquacult Rep 3:198-208

Hamasaki K, Kitada S (2008) The enhancement of abalone stocks: lessons from Japanese case studies. Fish Fish 9: 243-260

* Hamel JF, Conand C, Pawson DL, Mercier A (2001) The sea cucumber Holothuria scabra (Holothuroidea: Echinodermata): its biology and exploitation as bêche-de-mer. Adv Mar Biol 41:129-223

*Hamel JF, Mercier A, Conand C, Purcell S, Toral-Granda TG, Gamboa R (2013) Holothuria scabra. The IUCN Red List of Threatened Species 2013: e.T180257A1606648. http://dx.doi.org/10.2305/IUCN.UK.2013-1.RLTS.T1802 57A1606648.en (accessed on 6 November 2017)

*Hammond LS (1983) Nutrition of deposit-feeding holothuroids and echinoids (Echinodermata) from a shallow reef lagoon, Discovery Bay, Jamaica. Mar Ecol Prog Ser 10:297-305

Hastie T, Tibshirani R, Friedman J (2011) The elements of statistical learning: data mining, inference, and prediction, 2nd edn. Springer, New York, NY

Heasman MP (2006) In pursuit of cost-effective fisheries enhancement of New South Wales blacklip abalone, Haliotis rubra (Leach) fishery. J Shellfish Res 25:211-224

*Hines A, Johnson E, Young A, Aguilar R and others (2008) Release strategies for estuarine species with complex migratory life cycles: stock enhancement of Chesapeake blue crabs, Callinectes sapidus. Rev Fish Sci 16:175-185

Irlandi EA (1994) Large- and small-scale effects of habitat structure on rates of predation: how percent coverage of seagrass affects rates of predation and siphon nipping on an infaunal bivalve. Oecologia 98:176-183

Juinio-Meñez MA, de Peralta GM, Dumalan RJP, Catbagan TO (2012) Ocean nursery systems for scaling up juvenile sandfish (Holothuria scabra) production: ensuring opportunities for small fishers. In: Hair C, Pickering T, Mills D (eds) Asia-Pacific Tropical Sea Cucumber Aquaculture. ACIAR Proc No. 136, p 57-62

Juinio-Meñez MA, Tech ED, Ticao IP, Gorospe JRC, Edullantes CMA, Rioja RAV (2017) Adaptive and integrated culture production systems for the tropical sea cucumber Holothuria scabra. Fish Res 186:502-513

Kenyon RA, Loneragan NR, Hughes J (1995) Habitat type and light affect sheltering behaviour of juvenile tiger prawns (Penaeus esculentus Haswell) and success rates of their fish predators. J Exp Mar Biol Ecol 192:87-105

Lavitra T, Rasolofonirina R, Eeckhaut I (2010) The effect of sediment quality and stocking density on survival and growth of the sea cucumber Holothuria scabra reared in nursery ponds and sea pens. West Indian Ocean J Mar Sci 9:153-164

Leber KM (2012) Marine fisheries enhancement, coming of age in the new millennium. In: Christou P, Savin R, Costa-Pierce BA, Misztal I, Whitelaw CBA (eds) Sustainable food production. Springer, New York, NY, p 1139-1157 
Leber KM, Cantrell RN, Leung PS (2005) Optimizing costeffectiveness of size at release in stock enhancement programs. N Am J Fish Manage 25:1596-1608

Loneragan N, Haywood M, Heales D, Kenyon R, Pendrey R, Vance D (2001) Estimating the influence of prawn stocking density and seagrass type on the growth of juvenile tiger prawns (Penaeus semisulcatus): results from field experiments in small enclosures. Mar Biol 139:343-354

Lovatelli A, Conand C, Purcell S, Uthicke S, Hamel JF, Mercier A (eds) (2004) Advances in sea cucumber aquaculture and management. FAO Fish Tech Pap 463, FAO, Rome

Mercier A, Battaglene SC, Hamel JF (1999) Daily burrowing cycle and feeding activity of juvenile sea cucumbers Holothuria scabra in response to environmental factors. J Exp Mar Biol Ecol 239:125-156

Mercier A, Battaglene SC, Hamel JF (2000) Periodic movement, recruitment and size-related distribution of the sea cucumber Holothuria scabra in Solomon Islands. Hydrobiologia 440:81-100

Moksnes PO (2002) The relative importance of habitatspecific settlement, predation and juvenile dispersal for distribution and abundance of young juvenile shore crabs Carcinus maenas L. J Exp Mar Biol Ecol 271:41-73

Molony BW, Lenanton R, Jackson G, Norriss J (2003) Stock enhancement as a fisheries management tool. Rev Fish Biol Fish 13:409-432

Munro JL, Bell JD (1997) Enhancement of marine fisheries resources. Rev Fish Sci 5:185-222

Okuzawa K, Maliao RJ, Quinitio ET, Buen-Ursua SMA and others (2008) Stock enhancement of threatened species in Southeast Asia. Rev Fish Sci 16:394-402

* Oliver MD, Stewart R, Mills D, MacDiarmid A, Gardner C (2005) Stock enhancement of rock lobsters (Jasus edwardsii): timing of predation on naive juvenile lobsters immediately after release. NZ J Mar Freshw Res 39: 391-397

Paterson AW, Whitfield AK (2000) Do shallow-water habitats function as refugia for juvenile fishes? Estuar Coast Shelf Sci 51:359-364

Purcell SW (1997) Quantifying organic content of material from coral reefs. In: The Great Barrier Reef, science, use and management: a national conference: proceedings, Vol 2. Great Barrier Reef Marine Park Authority, Townsville, p 61-66

Purcell SW (2004a) Management options for restocked trochus fisheries. In: Leber KM, Kitada S, Blankenship HL, Svasand T (eds) Stock enhancement and sea ranching: developments, pitfalls and opportunities. Blackwell, Oxford, p 233-244

Purcell SW (2004b) Criteria for release strategies and evaluating the restocking of sea cucumbers. In: Lovatelli A, Conand C, Purcell S, Uthicke S, Hamel JF, Mercier A (eds) Advances in sea cucumber aquaculture and management. FAO Fish Tech Pap 463:181-191

Purcell SW (2010) Diel burying by the tropical sea cucumber Holothuria scabra: effects of environmental stimuli, handling and ontogeny. Mar Biol 157:663-671

Purcell SW (2012) Principles and science of stocking marine areas with sea cucumbers. In: Hair C, Pickering T, Mills $\mathrm{D}$ (eds) Asia-Pacific tropical sea cucumber aquaculture. ACIAR Proc No.136, p 92-103

Purcell SW (2014) Value, market preferences and trade of beche-de-mer from Pacific Island sea cucumbers. PLOS ONE 9:e95075
Purcell SW, Cheng YW (2010) Experimental restocking and seasonal visibility of a coral reef gastropod assessed by temporal modelling. Aquat Biol 9:227-238

* Purcell SW, Simutoga M (2008) Spatio-temporal and sizedependent variation in the success of releasing cultured sea cucumbers in the wild. Rev Fish Sci 16:204-214

* Purcell SW, Blockmans BF, Nash WJ (2006) Efficacy of chemical markers and physical tags for large-scale release of an exploited holothurian. J Exp Mar Biol Ecol 334:283-293

Purcell SW, Samyn Y, Conand C (2012a) Commercially important sea cucumbers of the world. FAO Species Catalogue for Fishery Purposes No. 6. FAO, Rome

* Purcell SW, Hair CA, Mills DJ (2012b) Sea cucumber culture, farming and sea ranching in the tropics: progress, problems and opportunities. Aquaculture 368-369:68-81

Purcell SW, Conand C, Uthicke S, Byrne M (2016) Ecological roles of exploited sea cucumbers. Oceanogr Mar Biol Annu Rev 54:367-386

R Development Core Team (2010) R: a language and environment for statistical computing. R Foundation for Statistical Computing, Vienna

Ray M, Stoner AW (1995) Growth, survivorship, and habitat choice in a newly settled seagrass gastropod, Strombus gigas. Mar Ecol Prog Ser 123:83-94

Ridgeway G (2017) Gbm: generalized boosted regression models. https://CRAN.R-project.org/package=gbm (accessed on 23 June 2017)

Roberts RD, Keys EF, Prendeville G, Pilditch CA (2007) Viability of abalone (Haliotis iris) stock enhancement by release of hatchery-reared seed in Marlborough, New Zealand. J Shellfish Res 26:697-703

Robinson G, Slater MJ, Jones CLW, Stead SM (2013) Role of sand as substrate and dietary component for juvenile sea cucumber Holothuria scabra. Aquaculture 392-395: 23-25

* Rochette R, Maltais MJ, Dill LM, Himmelman JH (1999) Interpopulation and context-related differences in responses of a marine gastropod to predation risk. Anim Behav 57:977-987

Kuiz GM, Hines AH, Posey MH (1993) Shallow water as a refuge habitat for fish and crustaceans in non-vegetated estuaries: an example from Chesapeake Bay. Mar Ecol Prog Ser 99:1-16

* Schiel DR, Welden BC (1987) Responses to predators of cultured and wild red abalone, Haliotis rufescens, in laboratory experiments. Aquaculture 60:173-188

Shiell G (2004) Field observations of juvenile sea cucumbers. SPC Beche-de-mer Inf Bull 20:6-11

* Slater MJ, Jeffs AG (2010) Do benthic sediment characteristics explain the distribution of juveniles of the depositfeeding sea cucumber Australostichopus mollis? J Sea Res 64:241-249

* Slater MJ, Carton AG, Jeffs AG (2010) Highly localised distribution patterns of juvenile sea cucumber Australostichopus mollis. NZ J Mar Freshw Res 44:201-216

Tanaka M (2000) Diminution of sea cucumber Stichopus japonicus juveniles released on artificial reefs. Bull Ishikawa Prefect Fish Resour Cent 2:19-29

Tsiresy G, Pascal B, Plotieau T (2011) An assessment of Holothuria scabra growth in marine micro-farms in southwestern Madagascar. SPC Beche-de-mer Inf Bull $31: 17-22$

* Uthicke S, Karez R (1999) Sediment patch selectivity in tropical sea cucumbers (Holothurioidea: Aspidochirotida) 
analysed with multiple choice experiments. J Exp Mar Biol Ecol 236:69-87

Uthicke S, Purcell S (2004) Preservation of genetic diversity in restocking of the sea cucumber Holothuria scabra investigated by allozyme electrophoresis. Can J Fish Aquat Sci 61:519-528

Watanabe S, Sumbing JG, Lebata-Ramos MJH (2014) Growth pattern of the tropical sea cucumber, Holothuria scabra, under captivity. Jpn Agric Res Q 48:457-464

Wilson WH (1990) Competition and predation in marine soft-sediment communities. Annu Rev Ecol Syst 21: 221-241

Wilson SK, Graham NAJ, Polunin NVC (2007) Appraisal of visual assessments of habitat complexity and benthic composition on coral reefs. Mar Biol 151:1069-1076

Editorial responsibility: Omar Defeo, Montevideo, Uruguay
Wolfe K, Byrne M (2017) Population biology and recruitment of the vulnerable sea cucumber, Stichopus herrmanni, on a protected reef. Mar Ecol 38:e12397

Yamana Y, Hamano T, Miki K (2006) Distribution of the Japanese sea cucumber Apostichopus japonicus in the intertidal zone of Hirao Bay, eastern Yamaguchi Prefecture, Japan: suitable environmental factors for juvenile habitats. J Shimonoseki Univ Fish 54:111-120

* Young AC, Johnson EG, Davis JLD, Hines AH, Zmora O, Zohar Y (2008) Do hatchery-reared blue crabs differ from wild crabs, and does it matter? Rev Fish Sci 16:254-261

* Zohar Y, Hines AH, Zmora O, Johnson EG and others (2008) The Chesapeake Bay blue crab (Callinectes sapidus): a multidisciplinary approach to responsible stock replenishment. Rev Fish Sci 16:24-34

Submitted: October 6, 2017; Accepted: December 4, 2017 Proofs received from author(s): January 24, 2018 